удК: 002.2(477)(091)(092) «17/19»

DOI: $10.26661 /$ zhv-2019-1-53-11

\title{
History of the Book in Creative Heritage of Mykhailo Hrushevskyi
}

\author{
V. 0. Krot \\ Kremenchug Mykhailo Ostrogradsky National University \\ volodyakrot@ukr.net \\ V. V. Krot \\ Kremenchug Mykhailo Ostrogradsky National University
}

Key words: bibliology, books, handwriting, princes, monasteries, printing, M. Hrushevskyi.
The article examines M. Hrushevskyi's views on book development in Ukraine, from period of prince ruling to the beginning of the 20th century. Special attention is given to positive influence of clergy, monasteries and princes on book products formation in Kievan Rus and its distribution to regions. The authors pointed to dependence of book writing on political situation in different periods of Ukraine's history. Particular attention is paid to book printing and its impact on national consciousness. The negative results of Tsarism anti-Ukrainian policy regarding publishing books in our region, dating from the 18th century to beginning of the 20th century, were noted. The views of M. Hrushevskyi on Ukrainian culture development, in particular bibliology during early and late modern periods of our history were revealed.

\section{Історія книги в творчій спадщині Михайла Грушевського}

\section{B. О. Крот}

Кременчуцький національний університет імені Михайла Остроградського

\section{B. В. Крот}

\section{Кременчуцький національний університет імені Михайла Остроградського}

Ключові слова: книгознавство, книги, рукописи, князі, монастирі, друкарство, М. Грушевський.

\begin{abstract}
В статті досліджуються погляди М. Грушевського на процес розвитку книги в Україні, починаючи 3 княжої доби і до початку XX століття. Відзначено позитивний вплив духовенства, монастирів, князів на формування книжної продукції в Київській Русі та її поширення в регіони. Автори вказали на залежність рукописання від політичної ситуації в різні періоди нашої історії. Окрема уваги приділена книгодрукуванню та його впливу на свідомість громадянства. Відзначено негативні наслідки антиукраїнської політики царизму щодо видання книг в нашому краї, починаючи XVIII і до початку XX століття. Розкрито погляди М. Грушевського на розвиток української культури, зокрема книгознавства, в новий та новітні періоди нашої історії.
\end{abstract}

The outstanding Ukrainian historian Mykhailo Hrushevskyi made a significant contribution to the study of Ukrainian culture. According to his studies, the book has played an important role in the spiritual development of our people. Its history was inextricably linked with the past of the Ukrainians. All disagreements and tragedies had influenced on Ukrainian books. Unfortunately, contribution of the scholar to study of Ukrainian books history is not sufficiently highlighted in the national historiography. At the point, we have certain works in which the scholar's achievements in bibliography are noted. First of all, there are the works of I. Tsybenko [1, 2] and M. Tymoshyk [3]. Hrushevskyi's ideas regarding the book influence on society at different times were analysed in those works.
The purpose of our research is to study the history of Ukrainian books in different periods of Ukrainian people national development. The research object is handwritten and printed publications as factors of development of religious and national consciousness of the Ukrainians. As research sources there are used historical and journalistic works of M. Hrushevskyi, such as the multi-volume "History of Ukraine-Ruthenia", "History of Ukrainian literature", as well as well-known scholar's works "Illustrated History of Ukraine", "Cultural-National Movement in Ukraine in the 16th - the 17th centuries" and journalistic articles, in particular, "Ukrainian Old-Books", "In Defense of the Book", etc.

There are two stages in the history of book development: 1 ) handwriting; 2 ) printing. The first 
stage was continued during the period of Kievan Rus and the Polish-Lithuanian Commonwealth since the 10th to the middle of the 16th centuries. The second one began in Western Europe since the middle of the 15th century, and became widespread in Ukraine at the second half of the 16th century.

While exposing the history of the book, M. Hrushevskyi approved that books had arrived to Rus' along with Christianity. The year 860 was considered as the starting point [5, P. 14]. This fact was perceived by many scholars as an evidence of Ruthenian language and literature early self-sufficiency. The first books were religious and mainly imported to Rus' from Byzantium. Those books were distributed among the clergy, princes and boyars. M. Hrushevskyi emphasized that the book science began under Volodymyr the Great, but took effect under Yaroslav the Wise. The scholar described this as follows: "Yaroslav sowed book words in the hearts of loyal people, and we reap the benefits of book studies" [5, P. 53]. The historian believed that representatives of educated strata were mostly gentlemen of the cloth, although education was supported by the princes and prominent boyars; commonly known book loving side of Yaroslav and erudition of Svyatoslav Yaroslavovich, Vsevolod, and Monomakh [5, P. 14].

Monasteries actively educated its flock. M. Hrushevskyi stated that according to the Student Statute, a library should be in every monastery, and attendance was recommended for brethren at certain time. According to the words of the Rev. Nestor, some of monks had their own collections of books, and they were engaged in reading with great diligence. A monastic library, which probably existed, was located in the church choir. Analysing these facts, M. Hrushevskyi came to conclusion that a book was common phenomenon in the monastery and it was no special meaning. Monks were the authors of the majority of spiritual works [4, P. 418].

Domestic-made books appeared in Rus' in about the middle of the 11th century. The first manuscript (so-called Ostromyrov Gospel, written in Kyiv) was dated year 1057. According to the historian, book tradition in Rus' was established approximately 60-70 years after the adoption of Christianity [5, P. 16]. Analysing the distribution, the scientist identified separate periods in it. The first of them falls on the middle of the 11th - the first half of the 12th century, time of the highest cultural and political rise of Kyiv state. After that the process of its collapse has begun. It is ended with the disastrous Mongol conquest of 1240 . Books were affected by the political situation in the country. M. Hrushevskyi emphasized that at the first stage Kyiv was the undisputed cultural centre, where majority of book production took place. Boors were written and duplicated in monasteries. At the second stage, in the middle of the 12th - the 13th centuries there was the gradual outflow of book products to the regions, primarily to the North. Political situation and the rivalry between Kyiv and Suzdal, in particular, affected the book craft. The scholar pointed to the fact that at North were hidden the majority of Ukrainian works of the 11th century, and few later works, when political and cultural life of the North and the South has already significantly departed, and Kyiv has ceased to be a real Metropolis as well as a source and model of education, literacy and culture of the whole Slavic East [5, P. 16].

The historian described the situation which had arisen in Ukrainian lands from the second half of the 14th to the first half of the 15th centuries as Dark Age. The scholar stated that book products had been really going through a period of deep stagnation [5, P. 14]. M. Hrushevskyi described the funds of the Suprassky Monastery library, founded by Metropolitan Joseph Soltan in the beginning of the 16th century, as an example of the book state in Ukrainian lands of that time [7, P. 338]. Having based on the analysis of the library catalogue, the scholar made general conclusions about the book products, which were spread at Ukrainian lands at the time, "This is not only the largest assortment, but also a very typical." [7, P. 342].

Dissemination of book printing in the middle of the 15th century did not immediately lead to radical changes in book status. At that time printed books resembled handwritten ones. According to M. Hrushevskyi, the first Cyrilic printed books appeared at the end of 15th century in Krakow, due to the efforts of Fyola. The forerunner of the late 16th century national renaissance was Zabludivka, the printing house of Khodkevych. It was founded by Moscow emigrants Ivan Fedorov and Pyotr Mstislavets on Belarus-Ukraine border at the estate of Hrehory Chodkiewicz. The first publication was the Gospel, begun in July 1568 and completed in March 1569.

In the last quarter of the 16th century 0stroh became the cultural centre of Ukraine. There were situated the best scholar facilities of that time, high school, and printing house. The scholar analysed literary production in detail, "Along with the Ostroh Academy, one way or another, comes the venerable part of what appeared in the modern journalistic-theological polemical literature in Ukraine and Belarus for a quarter of a century. From the "Key" of H. Smotrytskyi to "Trainos" written by his son" [7, P. 495]. 
In the 17th century Kyiv became a new cultural centre of Ukraine. The historian linked the further process of Ukrainian national renaissance to this city. In the ancient capital of Rus', the book production was actively developing. The further development of national culture was not possible without it. In Kyiv, due to efforts of the Orthodox hierarchy and brotherhood, a powerful printing house was created. Pechersk monastery, headed by Abbot Pletenetsky, played a significant role in elevating the cultural life in Kyiv. In 1615 he relocated the printing house from Lviv to the monastery. Assessing this work, M. Hrushevskyi wrote, "The new Pechersk printing house has released more books for fifteen years (1615-1630) than there had been released before it in all over Ukraine. There were a great equipment and good leaders devoted to their work" [6, P. 263].

In the notes to the seventh volume of "History of Ukraine-Ruthenia" M. Hrushevskyi submitted a complete list of works published by Pechersk Monastery printing house during 1617-1632. Of course, there were mostly religious works, which were used during worship services, such as "Psaltyr" or "Chasoslov". There were works of the Fathers of John Chrysostom Church, polemical works in defence of Orthodoxy, burial poem of P. Sahaidachnyi.

Due to election of P. Mohyla in 1632 as Metropolitan of Kyiv and Orthodox Church legalization Kyiv became a new cultural centre of Ukraine and Belarus. Describing the activities, M. Hrushevskyi wrote, "Kyiv religious and cultural institutions merged for several decades into one great powerful institution, led by the strong hand of Mohyla. His individuality highly influenced the entire nature of the cultural and religious life of those times, and Ukrainian cultural life in general." [8, P. 424]. Among the printed editions published at that time, the historian noted that "Trebnyk" is one of the largest monumental editions, its prosperous font in purely typographic manner is also one of the great works of Ukrainian graphics.

With the accession of Ukraine to the Russian state in 1654 , book printing situation began to change. "Kyiv editions were often banned in Moscow, and in the 1670's and 80's with support of Patriarch Joakim a persecution of Ukrainian books was increased." [6, P. 424]. When in 1686, with the submission of the Ukrainian Church to Mos- cow Patriarchate, Russian authorities were able to ban Ukrainian books not only in Moscow but also all over Ukraine, "then the Moscow authorities' position highly influenced publishing movement." Soon it became a lingual and national matter. We can see how the royal government made attempts to control publishing business [6, P. 263]. The Poltava battle of 1709 and then the decree of 1720 were aimed at destroying any Ukrainian printed edition. M. Hrushevskyi gave an example that in year 1726 one was about to print in Kyiv the Akathist to saint Varvara, written by Metropolitan, but this was allowed only on condition that it would be translated into Russian. The scholar stated that in the 18th century a book art deteriorated along with the destruction of Ukrainian version of Church Slavonic language.

In the second half of 19th century, royal government did everything to destroy Ukrainian writing as a phenomenon of Ukrainian national culture. The proof of this policy was the Valuev Circular of 1863 and the Ems Ukaz of 1876. In order to publish book in Ukrainian, a special permission from the authorities was required. The situation slightly improved after the revolution of 1905, when the government cancelled the ban of Ukrainian-language printed publications. However, at that time Tsarism continued to hinder the development of Ukrainian books. On this occasion, I think it is necessary to quote a historian's words of 1908, aimed at protecting the Ukrainian book, which unfortunately have not lost their relevance today, "if you are interested in a book in Russian, you should borrow it but a book in Ukrainian you should buy and put on the table as a proof of your attentiveness and sincerity to Ukrainian cultural life and as an evidence of this life itself." [10, P. 53].

Analysing the life and the work of the Great Ukrainian, we come to the conclusion that he had researched book state in different periods of Ukrainian history and emphasized its beneficial influence on Ukrainian society. A role of printed publications in national renaissance period has increased. The scholar was convinced that it is impossible to educate Ukrainian people and turn it into a full-fledged nation without a book. Therefore, his creative heritage and practical activities were aimed to awaken interest in Ukrainian book. 


\section{References}

1. Cybenko, I. (2011), "Bibliological culture in work of Mykhailo Hrushevsky”, Visnyk Knyzhkovoji palaty, vol. 9, pp. $33-36$.

2. Cybenko, I. (2015), "Scholar and publishing activities of M. Hrushevsky in conditions of development Ukrainian national culture", Visnyk Knyzhkovoji palaty, vol. 11, pp. 34-37.

3. Tymoshyk, M. (2007), Istoriia vydavnychoi spravy [History of Publishing], 2nd ed, Nasha kuljtura i nauka, Kyiv, Ukraine.

4. Hrushevsky, M. (2007), Narys istorii Kyivs'koi zemli vid smerti Yaroslava do kintsia XIV stolittia [Essay on the history of Kyiv land from the Yaroslav death to the end of XIV century], Naukova dumka, Kyiv, Ukraine.

5. Hrushevsky, M. (1993), Istoriia ukrains'koi literatury [History of Ukrainian Literature], Vol. 2, Lybidj, Kyiv, Ukraine.

6. Hrushevsky, M. (1992), Iliustrovana istoriia Ukrainy [Illustrated History of Ukraine], Naukova dumka, Kyiv, Ukraine.

7. Hrushevsky, M. (1995), Istoriia Ukrainy-Rusy [History of Ukraine-Ruthenia], (Vols. 1-11); Vol. 6, Naukova dumka, Kyiv, Ukraine.

8. Hrushevsky, M. (1995), Istoriia Ukrainy-Rusy [History of Ukraine-Ruthenia], (Vols. 1-11); Vol. 7, Naukova dumka, Kyiv, Ukraine.

9. Hrushevsky, M. (2009), “Ukrainian Early Printed Books”, Tvory v 50-ty tomakh, vol. 9, pp. 239-242.

10. Hrushevsky, M. (2005), “To defense of Ukrainian book”, Tvory v 50-ty tomakh, vol. 3, pp. 52-54. 